\title{
Recenzja książki: Jerzy Oniszczuk, 2019. Sztuka rozumienia. Poszukiwania filozofii archaicznej, Warszawa: Oficyna Wydawnicza SGH
}

\section{Streszczenie}

Artykuł jest recenzją książki Sztuka rozumienia. Poszukiwania filozofii archaicznej (2019) autorstwa Jerzego Oniszczuka. Autor recenzji omawia zawartość książki, komentuje wyniki przeprowadzonych analiz oraz sposób ich prezentacji.

Słowa kluczowe: filozofia polityki, filozofia prawa

Kody klasyfikacji JEL: B11, Y30, Z00

1 Uczelnia Jana Wyżykowskiego, Wydział Nauk Społecznych, https://orcid.org/0000-0003-0850-6025 


\title{
Book review: Jerzy Oniszczuk, 2019. Sztuka rozumienia. Poszukiwania filozofii archaicznej (The art of understanding: Searching for archaic philosophy). Warszawa: Oficyna Wydawnicza SGH
}

\begin{abstract}
The article is a review of the book titled Sztuka rozumienia. Poszukiwania filozofii archaicznej [The art of understanding: Searching for archaic philosophy] (2019) by Jerzy Oniszczuk. The author of the review discusses the content of the book and comments on the results of the analyzes and the method of their presentation.
\end{abstract}

Keywords: philosophy of politics, philosophy of law

JEL Classification Codes: B11, Y30, Z00

Jerzy Oniszczuk, autor książki, jest profesorem teorii i filozofii prawa o ogromnym i przede wszystkim różnorodnym dorobku naukowym. Kładzie w nim wyraźny akcent na budowanie i poszukiwanie pojęć, ich historii i intelektualnych zmagań $\mathrm{z}$ badaną materią. Recenzowana praca stanowi fundamentalną, a może i podstawową książkę w swojej dziedzinie - nie można jej pominąć przy próbach snucia refleksji nad starożytnym światem. Jest obszerna, obejmuje w zasadzie wszystkie ważne wątki kształtowania się myśli w okresie starożytnym.

Autor opracował temat $z$ pozycji teoretyka prawa, ale nie pominął aspektów filozoficznych. Są one widoczne przede wszystkim w metodologii, w badaniu: analizowana jest myśl filozoficzna, a jednocześnie zbudowany warsztat analizy jako sfera rozwojowa dla książki. Są to co najmniej dwa różne obszary aspektów filozoficznych, nie zawsze właściwie dostrzegane i odróżniane w doktrynie prawa, nie mówiąc o naszej teorii prawa. Problem warsztatu nie jest znowu taki prosty, a już z pewnością oczywisty, a jego dystynkcje są zawsze złożone, czego świadomość pogłębiłaby znacząco prace pisane pod hasłem teorii prawa. Ona, jak każda teoria, jest, a przynajmniej bywa w potrzebie, ekskluzywna, czego nie da się jednak załatwić definicją. Trzeba tę ekskluzywność wydobyć, chyba jako odrębny zarys teorii. A myślę o tym właśnie pod wpływem recenzowanej pracy.

Książka nie ma charakteru dydaktycznego, nie jest bowiem podręcznikiem, choć nie pomija i takich elementów. Zapewne, nie jest „gęstym” opisem starożytnych materii, na zasadzie „im więcej, tym lepiej”. Autor ma znajomość starożytności i przede wszystkim zdolność jej rozumienia. Wie, że czym innym jest pewna formacja, w tym wypadku świata czy bardziej umysłów i świata. Prowadzi analizę ku wartościom również estetycznym w refleksyjności starożytnych. Widać to w szczególności 
na przykładzie przedstawiania nurtu pitagorejskiego. Autor to znakomicie dostrzega i wydobywa role nurtów, które są kluczem podziału pracy na części.

O kulturze, także w okresie archaicznym, pisze jako o wyrafinowanej, przypisując jej rozwój temu okresowi w Grecji. Jest ona (i słusznie) punktem wyjścia dla całej książki i jej motywem. To prowadzi dalej do wielkich pytań dotyczących zarówno kosmosu, jak i praw kierujących ludźmi. Koncepcja rozumienia budowana jest dla poszczególnych kierunków, szkół, np. pitagorejskich, by następnie interpretować ich materie. Różnorodność, z którą się tu spotykamy, zakłada wielość koncepcji.

Znaczące dla tej pracy jest też, że ta różnorodność, różnorodność koncepcji jest budowana w interpretacji odmiennej od wykładni. Nie ma rozumienia bez interpretacji właśnie. Oczywiście, byłoby jeszcze lepiej, gdyby Autor wydobył kategorialność tego zabiegu, również jako dążenia. To w pracy jest - wymaga tylko odpowiedniego generowania, nowej rozprawy. Odróżnia to, co robią empirycy, od postawy teoretyków. Idąc tu za Arystotelesem, ukazuje, co może osiągnąć teoretyk we wzniosłości poznawczej.

Praca ma kilka poziomów: po pierwsze z powodu tego, co działo się w Grecji, po drugie z powodu różnorodności odtwarzanej intelektualnie w książce, a po trzecie z powodu dążenia do stworzenia wspólnej płaszczyzny dla tych obszarów. Charakterystyczne jest, że Autor, nawet gdy wchodzi w materie empiryczne, unika konkluzywności, prześladujących teorie prawa, w których mamy już wyczerpane tematy. Nic tedy dziwnego, że postulat „mądrości prawniczej” (s. 13) dobrze się osadza w recenzowanej pracy. Wraz z tym idą uwagi wskazujące wartości w rozważanych kierunkach. Przyznaję, że Autor w całej pracy docenia „miękką” filozofię, z którą ma do czynienia, i odpowiednio przypisuje walory terminom wyszukanym w tej filozofii.

Autor swoją pogłębioną wiedzę wykorzystuje do zaznaczania związków między danymi poglądami myślicieli a podobieństwem poglądów innych twórców. Jest to znakomity przykład na holistyczne traktowanie omawianych dziejów. I co ważniejsze akurat przy temacie tej książki, tworzy ujęcia systemowe przedstawianych myślicieli. I chociaż to w pracy występuje, w przyszłych wydaniach dobrze byłoby rozważyć, które z tych związków mają, i dlaczego, postać wertykalną, a które - horyzontalną. Mogłoby to przyczynić się też do spojrzenia na wszystko od strony poziomów abstrakcyjności ujęć, no i transcendencji. Na razie zostawmy to, tym bardziej że recenzowana praca ma wielorakie inspiracje - i dobrze, bo przecież ona o rozumieniu będąc, ma być twórcza, a nie jedynie odtwórcza. Autor tę różnicę widzi i wedle niej prowadzi rozważania. Dlatego też nie zaniedbuje krytyki, zadając często pytanie: „dlaczego?”, zwłaszcza w sporze między prawem (nomas) a naturą (physis) (s. 579). Wykorzystując znajomość metodologii, podkreśla przede wszystkim wagę 
rozumienia. Są to te wątki pracy, które zasługują na szczególną uwagę. Gdyby się oddzielnie nimi zająć, otrzymalibyśmy zwiększoną porcję metodologii tamtego czasu. Filarem Europy jest, jak wiadomo, m.in. filozofia grecka. W tym kontekście w pracy podkreśla się, że człowiek jest miarą prawa (s. 172).

Autor, wykazując się wiedzą pozwalającą na wszechstronność problemową, pokazuje przejścia między poszczególnymi filozofiami, proponuje tezy o dużych walorach poznawczych, zwłaszcza wychodząc od archaicznej myśli (s. 587) czy pisząc o związkach między infrastrukturą a umysłem (s. 587), co z pewnością nadawałoby się na osobną pracę. Przy holistycznym traktowaniu człowieka Autor pokazuje zasady ze względu na filozofię, nie mieszając tego bez potrzeby z teorią prawa (s. 214-216). W pracy dostrzeżono w myśleniu przedstawianym nowy sposób rozumowania. Autor widzi je nie jako spotykany w literaturze ozdobnik wśród ozdobników starożytności, lecz dostrzega, skąd ono wypływa, merytorycznie wzbogacając rozumienie. Robi to $\mathrm{z}$ naukową dyscypliną, wykazując się przy tym szacunkiem dla starożytności.

Z poczuciem dbałości, czyniąc zadość metodologii, widzi w myśli Heraklita wewnętrzny ukryty rytm natury. Przywiązuje wagę do tych wypowiedzi myślicieli, które, z racji wewnętrznego zróżnicowania, są dobrym punktem wyjścia do rekonstruowania stanu rozumienia. W rozumieniu pojawia się zagadnienie opisu powstawania świata, uniwersum, metafizyczne założenia, a więc terminy nie z zakresu rozumień powierzchownych czy zgoła intuicyjnych. Autor robi z nich użytek, łącząc je zwłaszcza z kosmologią, stanowiącą - myślę - swoistą płaszczyznę dociekań myślicieli i osobno ich przedmiot zainteresowań światem (s. 431). To zostało głęboko dostrzeżone $\mathrm{w}$ pracy i na różne sposoby wydobyte. $\mathrm{W}$ tym kontekście pozostają poszukiwania myśli traktujących o mikrokosmosie, o człowieku i duszy. W książce daje się dostrzec pójście śladami rozwoju w kierunku zagadnień dużej wagi i znaczącej filozofii jońskiej. W tej sferze poszukuje się zwłaszcza problematyki ruchu, bo też ona bierze się ze świata głównie mentalnego. Wątek ruchu pojawia się od początku książki i jest prowadzony bardzo ciekawie przez całą atomistykę, człowieka i jego duszę. Jest pomocny w poszukiwaniach rozumień bóstw czy ogólnie religii. To wchodzi w zagadnienia uczuć i myśli, wiedzy zmysłowej rozumowej. Już samo to rozróżnienie nie może ujść uwagi rozumnego czytelnika. Pisze się tu choćby o wiarygodności zmysłów. Problematyka prawdy jest wydobywana na płaszczyźnie myśli w całej pracy. Są też wtręty odnośnie do logiki i matematyki jako priorytetu. „Każde doznanie jest prawdziwe, ale prawdziwe dla tego, kto je doświadcza” (s. 435).

Ważną kwestią w omawianej pracy jest poznanie. Ono zastanawia Autora w całości rozważań. Wraca do tego przy różnych okazjach, głównie wspominając Demokryta i tam, gdzie ujawnia się świat rzeczywisty. Nie pomija próżni, która i dzisiaj rodzi wiele pytań. Zawsze rodziła. Nie pomija też impresji i poznania. Problematyka świata 
rzeczywistego a mentalnego zajmuje znaczące miejsce. Jest źródłem pytań, których się tu nie unika, i co ważniejsze, dotyczą one zagadnień abstrakcyjnych i ogólnych. Właśnie, zwracanie uwagi na to, co abstrakcyjne jest w problematyce rozumienia wyraźnie przez Autora dostrzegane i we własnych sądach wykorzystywane.

Autor stosuje odpowiednio słowo „mechanizm”, budując z jego pomocą procesy właściwe dla rozumowań i ich ciągów. Nie pomija tutaj zmysłu stykania się. Wykorzystuje wszystko, co służy głównemu nurtowi pracy. Dotyczy to także obrazów, przede wszystkim podobieństwa w układzie horyzontalnym w grupie omawianych myślicieli. Nie pomija momentu samoświadomości, dając też okazję psychologom do szukania ważnych dla nich archetypów, jak np. pogodny charakter. Czego tu nie ma? To jest dobre pytanie w ocenie tej książki. Jest wielość zagadnień potraktowanych niepowierzchownie.

Autor nie pominął prawa, choć nie jest pewne, czy daje się je pomieścić w sztuce rozumienia. Demokryt uważał, że cel społeczności zawiera się w pomyślności państwa. Wiązał to z obywatelskim poczuciem mieszkańców. To brzmi całkiem współcześnie, bo też zawsze tam, gdzie występowały zbiorowości, nie dało się odejść od polis, która zapewne musiała być efektem wyobraźni niewolnej od rozumienia. Jerzy Oniszczuk polis poświęcił osobną książkę, odpowiednio zgłębiając tę instytucję, do której zasadnie wraca w recenzowanej pracy. Tu też pojawiają się wątki demokracji nie zawsze związane z jej niezbędnością. Bo też ona uniemożliwia osiągnięcie „idealnej wspólnoty" (s. 442). Zostawmy instytucje i ich oceny. To nie oznacza jednak, że $\mathrm{w}$ tym wypadku nie pojawiają się sfery z dziedziny rozumienia. Są tu dobroć i rozum jako kategorie, jednak napędzające myślenie, rozumienie itp. Demokryt nawoływał do umiarkowania, czyli pewnych postaw mentalnie nieobojętnych. Autor, przedstawiając swój stosunek do państwa, uznaje, że ma ono być projektowane w odniesieniu do idei, prawidłowo urządzone w przestrzeganiu prawa. Odpowiednio do pogłębiania idei władza jest postrzegana jako sztuka. Właśnie, choć państwo i władza są odpowiednio zinstytucjonalizowane, wypowiedzi o nich związane są przede wszystkim z ideami, co jest charakterystyczne dla ówczesnych umysłów. Wtedy myśl, idee były dominujące, jak znacząco uzasadnia tytuł tej książki.

Prawa tamtego czasu nie uważa się za dzieło bogów, nie wprowadzano go do panteonów myśli, ale też nie trywializowano. W książce widać jego instrumentalną rolę, choć jest ona ogólna. Ludzie ustanawiają prawo. Toteż nie ma ono „charakteru ostatecznego i nie odzwierciedla jakiegoś rozumnego, złożonego porządku” (s. 448), jest w ruchu, ale w ruchu co do prawa czy też w ruchu co do myśli. Autor odwołuje się w tym wypadku do tego, że jest „refleksem rozumu”. Jest, ale na jakim poziomie? Grecy co do tego mieli zapewne pomysł, a Autor w swoich poprzednich pracach do tego wraca. Stanowienie prawa, idea prawa, były poszukiwaniem równowagi. 
Na drodze ówczesnego myślenia zatrzymuje nas koncepcja umownego charakteru prawa, bo też ono jest tworem zapewne rozumnym, umysłu, a nade wszystko więzi. Więc jest antytezą physis.

Jerzy Oniszczuk wchodzi w tę antytezę nie po to, by mówić, co jest pierwsze, lecz po to, by zgłębiać tamto prawo - w myślach i w naturze. Idzie dalej i za Demokrytem sięga do języka porozumień i ich rozwoju. Zapewne wyłania się tu też problematyka prawnonaturalna, co Autor dostrzega i odpowiednio akcentuje, aż do pozytywistycznych nawiązań. Nie pomija zagadnień o związkach filozofii z etyką. Ta ostatnia przewija się przez całą książkę, albowiem zagadnienie dobra nie mogło się nie pojawiać przy okazji pytań o filozofię, która sięgając swoich początków, odkrywa także związki człowieka ze zwierzętami (s. 442).

Temu wszystkiemu nie było obce szczęście, w jego poszukiwaniu zwłaszcza. Przywołując Demokryta, „Szczęśliwy jest ten, kto ma i majątek, i rozum, kto mając ograniczone środki, cieszy się spokojem ducha”. Nawet dzisiaj, gdy sięgamy do Władysława Tatarkiewicza, odnajdujemy elementy całkiem współczesne. Na przykład unikanie zawiści. Toteż zajmując się rozumieniem, nie można pominąć sfery duchowości, od której należy rozpoczynać przebiegi rozumienia. Tak jest przecież z pogodnym charakterem uchodzącym w tym wypadku za determinację. Wychodząc od tego, znajdujemy odpowiednie przejścia do cnót odwagi, dzielności oraz siły ducha - tych przymiotów, z których starożytni wyprowadzali wiedzę o społeczeństwie i państwie. Autor dostrzega je jako elementy, dzięki którym rozumienie tamtego świata jest możliwe. Oczywiście, można to traktować jako coś rutynowego, powtarzającego się w podręcznikach. U Autora jest to stan rozważań nad wartościami, może i doskonałością myślenia. Wzniosłość myślenia ukazuje jako wartość, zwłaszcza w przedstawianych początkach, jak i rozwiniętej filozofii. To nie są tylko piękne opisy, można się dowiedzieć, jak na sfery etyczne wpłynęła tamtejsza atomistyka (s. 445).

Książka w dużej mierze poświęcona jest nauce, niemniej nie opuszcza, i to trzeba podkreślić, budowanych przez Autora związków z etyką, dobrym starożytnym wychowaniem. Pogłębione wrażliwości etyczne przyczyniały się m.in. do leczenia, rozwoju medycyny. Tu nie można pominąć całkiem współczesnych polskich wątków, choćby w osobach Antoniego Kępińskiego, twórcy humanistycznej psychiatrii, czy Andrzeja Szczeklika, wybitnego lekarza i zarazem humanisty. To obszary starożytności nadal aktualne. Tak, Autor widzi rozmiar analogii, choć trzeba z nimi ostrożnie. Autor narzucił sobie dyscyplinę i dobrze na tym wyszedł. A czytelnik dzięki niej dostrzeże, że owa sztuka rozumienia rozciąga się na pierwotność, naukę, filozofię i etykę. To jest niewątpliwy sukces Autora, świadczący o tym, że swoją wiedzą potrafi budować też struktury rozumienia i występujące między nimi heurystyczne związki. 
W recenzji pominięto obszerne pola relacji rozmaicie dostrzeganych w książce. Napisana erudycyjnie odznacza się też podejściem heurystycznym, intelektualnie aktywnym, co w połączeniu tych erudycji dało zapowiedź możliwych i następnych poszukiwań. 